\title{
Carbon to electricity in a solid oxide fuel cell combined with an internal catalytic gasification process
}

\author{
M. Konsolakis a,*, G. E. Marnellos b,c, A. Al-Musa d, N. Kaklidis b , I. Garagounis c,e, V. Kyriakou c,e \\ a School of Production Engineering and Management, Technical University of Crete, GR-73100, Chania, Crete, Greece \\ ${ }^{b}$ Department of Mechanical Engineering, University of Western Macedonia, GR-50100 Kozani, Greece \\ c Chemical Process \& Energy Resources Institute, CERTH, GR-57001 Thermi, Thessaloniki, Greece \\ d National Center for Combustion and Plasma Technologies, Water and Energy Research Institute, King Abdulaziz City for Science and Technology \\ (KACST), P.O. Box 6086, 11442, Riyadh, Saudi Arabia \\ ${ }^{\mathrm{e}}$ Department of Chemical Engineering, Aristotle University of Thessaloniki, GR-54124, Thessaloniki, Greece
}

\section{A R T I C L E I N F O}

\section{Article history:}

Received 12 October 2014

Accepted 8 December 2014

Published 20 April 2015

\section{Keywords:}

Direct carbon fuel cell

Internal catalytic gasification

Copper/ceria anode

Copper/ceria catalyst

\begin{abstract}
A B S T R A C T
This study explores strategies to develop highly efficient direct carbon fuel cells (DCFCs) by combining a solid-oxide fuel cell (SOFC) with a catalyst-aided carbon-gasification process. This system employs $\mathrm{Cu} / \mathrm{CeO}_{2}$ composites as both anodic electrodes and carbon additives in a cell of the type: carbon|Cu-CeO $/ 2 / \mathrm{YSZ} / \mathrm{Ag} \mid$ air. The study investigates the impact on in situ carbon-gasification and DCFC performance characteristics of catalyst addition and variation in the carrier gas used (inert He versus reactive $\mathrm{CO}_{2}$ ). The results indicate that cell performance is significantly improved by infusing the catalyst into the carbon feedstock and by employing $\mathrm{CO}_{2}$ as the carrier gas. At $800{ }^{\circ} \mathrm{C}$, the maximum power output is enhanced by approximately $40 \%$ and $230 \%$ for carbon $/ \mathrm{CO}_{2}$ and carbon/catalyst $/ \mathrm{CO}_{2}$ systems, respectively, compared with that of the carbon/He configuration. The increase observed when employing the catalyst and $\mathrm{CO}_{2}$ as the carrier gas can be primarily attributed to the pronounced effect of the catalyst on carbon-gasification through the reverse-Boudouard reaction, and the subsequent in situ electro-oxidation of $\mathrm{CO}$ at the anode three-phase boundary.
\end{abstract}

(C) 2015, Dalian Institute of Chemical Physics, Chinese Academy of Sciences. Published by Elsevier B.V. All rights reserved.

\section{Introduction}

Coal is generally viewed as an abundant and widely distributed fossil resource that is relatively inexpensive to extract. Currently, coal accounts for more than $30 \%$ of global energy consumption, and is the fastest-growing form of energy other than renewables [1,2]. However, coal use in conventional coal-fired electricity plants is constrained by Carnot's theorem on thermodynamic efficiency. In plants operating at subcritical pressures, the efficiency of converting thermal energy to electrical energy is typically less than $40 \%$. By contrast, fuel cells directly convert a fuel's chemical energy into electricity, which yields higher efficiencies and a smaller environmental footprint [3-6].

Direct carbon fuel cells (DCFCs) are electrochemical devices that directly exploit the chemical energy of solid carbonaceous materials $[7,8]$. DCFCs have the following advantages compared with conventional heat engines: (1) higher thermodynamic efficiency [9,10]; (2) direct use of a range of solid carbon reserves, such as biomass, coal, petroleum coke, pyrolytic carbon, and municipal organic wastes [9,11]; (3) lower $\mathrm{CO}_{2}$ emissions per unit of produced power, with these emissions more easily

* Corresponding author. Tel: +30 28210 37682; E-mail: mkonsol@science.tuc.gr; Web: www.tuc.gr/konsolakis.html DOI: 10.1016/S1872-2067(14)60262-X | http://www.sciencedirect.com/science/journal/18722067 | Chin. J. Catal., Vol. 36, No. 4, April 2015 
captured and sequestrated [12]; and (4) volumetric benefits associated with directly using coal rather than liquid or gaseous carbonaceous fuels $[13,14]$.

DCFCs can be categorized according to the electrolyte employed as either molten carbonate, molten hydroxide or solid oxide fuel cells (SOFCs). Carbon-fed SOFCs offer the established advantages of oxygen anion conducting solid oxide fuel cells. However, the limited interaction between the solid fuel and the solid electrolyte/electrode interface is the main factor hindering higher carbon electro-oxidation rates and higher associated DCFC performance. Molten carbonate/hydroxide electrolyte DCFCs have been proposed as an alternative approach; however, the corrosive nature of the electrolyte limits the durability of these systems [15-17].

Power generation in DCFCs follows a more complex pathway than in gas-fueled SOFCs with a combination of direct and indirect carbon electro-oxidation reactions potentially occurring simultaneously in DCFCs. Carbon particles in contact with the solid electrolyte/electrode interface at the anode are completely or partially electro-oxidized by oxygen anions $\left(\mathrm{O}^{2-}\right)$ transported through the electrolyte membrane from the air-exposed cathode, to form $\mathrm{CO}_{2}$ or $\mathrm{CO}$ via the following reactions:

$$
\begin{aligned}
\mathrm{C}+2 \mathrm{O}^{2-} & \rightarrow \mathrm{CO}_{2}+4 \mathrm{e}^{-} \\
\mathrm{C}+\mathrm{O}^{2-} & \rightarrow \mathrm{CO}+2 \mathrm{e}^{-}
\end{aligned}
$$

$\mathrm{CO}$ can be further electro-oxidized to $\mathrm{CO}_{2}$ through the following charge transfer reaction:

$$
\mathrm{CO}+\mathrm{O}^{2-} \rightarrow \mathrm{CO}_{2}+2 \mathrm{e}^{-}
$$

An alternative process has been recently established, which initially involves carbon-gasification to $\mathrm{CO}$ via the following reaction and its subsequent electro-oxidation to $\mathrm{CO}_{2}$ via reaction $(3)[7,8]$ :

$$
\mathrm{C}+\mathrm{CO}_{2} \rightarrow 2 \mathrm{CO}
$$

Reaction (4) is a non-electrochemical step, known as the reverse-Boudouard reaction, which is favored at temperatures higher than approximately $700{ }^{\circ} \mathrm{C}$. The chemical formation of CO via the reverse-Boudouard reaction does not itself contribute to cell power. However, the subsequent electrochemical oxidation of $\mathrm{CO}$ at the anode's three phase boundary (TPB) via reaction (3) significantly contributes to power generation. Tang et al. [18] reported that cell performance was notably improved by catalyzing the reverse-Boudouard reaction.

Based on the above reaction scheme, one approach to enhance DCFC performance is to combine a carbon-fueled SOFC with the internal catalytic $\mathrm{CO}_{2}$-gasification of carbon [19-22]. Here, gaseous $\mathrm{CO}$ and $\mathrm{CO}_{2}$ significantly contribute to power generation because $\mathrm{CO}$ can be electrochemically oxidized at the $\mathrm{TPB}$, while $\mathrm{CO}_{2}$ can undergo the reverse-Boudouard reaction to generate additional $\mathrm{CO}[23,24]$.

The present study aims to overcome the inherent limitations of DCFCs, associated with electrode kinetics and mass-transport phenomena, by introducing an in situ, catalyst-aided, carbon-gasification process. Instead of using highly corrosive molten electrolytes, this process aims to internally produce $\mathrm{CO}$, which can be diffused and electro-oxidized at TPB. To this end, $\mathrm{Cu} / \mathrm{CeO}_{2}$ catalysts were chosen on account of their established electronic conductivity, electro-oxidation activity for $\mathrm{CO}$ and hydrocarbons, and resistivity to poisoning by coke [25-29]. The catalysts were used both as carbon additives and anodic electrodes in a SOFC of the type: carbon $\mid \mathrm{Cu}-\mathrm{CeO}_{2} /$ yttria-stabilized zirconia (YSZ)/Ag|air.

To promote improvements in DCFC performance, this work investigates and discusses the impact on $\mathrm{CO}$ production and overall DCFC performance characteristics of the operating temperature, the catalyst infusion to carbon feedstock and the carrier gas $\left(\mathrm{He}\right.$ or $\mathrm{CO}_{2}$ ). The obtained results are further discussed on the basis of AC impedance spectroscopy studies.

\section{Experimental}

\subsection{Materials synthesis}

\subsubsection{Catalyst preparation}

$\mathrm{Cu} / \mathrm{CeO}_{2}$ catalysts with a nominal $\mathrm{Cu}$ content of $20 \mathrm{wt} \%$ were prepared using the wet-impregnation method. The $\mathrm{Ce}\left(\mathrm{NO}_{3}\right)_{3} \cdot 6 \mathrm{H}_{2} \mathrm{O}(99 \%$, Sigma-Aldrich) precursor was dissolved in distilled water, and the solution was heated under stirring to $125{ }^{\circ} \mathrm{C}$ until the water evaporated. The resulting sample was dried at $110{ }^{\circ} \mathrm{C}$ for $16 \mathrm{~h}$. The temperature was then increased at a heating rate of $5^{\circ} \mathrm{C} / \mathrm{min}$, and the sample was then calcined at $600{ }^{\circ} \mathrm{C}$ for $2 \mathrm{~h}$. The appropriate amount of $\mathrm{Cu}\left(\mathrm{NO}_{3}\right)_{2} \cdot 3 \mathrm{H}_{2} \mathrm{O}$ (99\%, Sigma-Aldrich) precursor was dissolved in distilled water and then impregnated into the calcined $\mathrm{CeO}_{2}$ support to yield a $\mathrm{Cu}$ content of $20 \mathrm{wt} \%$. The as-prepared composites were dried at $110{ }^{\circ} \mathrm{C}$ overnight, and then calcined at $600{ }^{\circ} \mathrm{C}$ for $2 \mathrm{~h}$.

\subsubsection{Feedstock preparation}

A commercial carbon-black (VXC72R, Cabot Corp.), either pure or mixed with $\mathrm{Cu} / \mathrm{CeO}_{2}$ catalyst at a 2:1 weight ratio (800 mg carbon:400 mg catalyst), was employed as feedstock. This specific carbon/catalyst proportion was determined in preliminary studies on the effect of catalyst loading on DCFC performance. For carbon/catalyst feedstock preparation, $800 \mathrm{mg}$ of carbon was initially diluted in $250 \mathrm{~cm}^{3} n$-hexane. The solution was agitated in an ultrasonic device for $15 \mathrm{~min}$, and then 400 mg of catalyst was added. The resulting solution was heated at $70^{\circ} \mathrm{C}$ for $4 \mathrm{~h}$ after which the $n$-hexane had totally evaporated.

\subsection{Materials characterization}

The surface area of the carbon sample and the carbon/catalyst mixture was determined by $\mathrm{N}_{2}$ adsorption-desorption at $-196{ }^{\circ} \mathrm{C}$ using multipoint Brunauer-Emmett-Teller (BET) analysis in an Autosorb-1 Quantachrome flow system. The BET surface area $\left(S_{\mathrm{BET}}\right)$ was determined at relative pressures in the range of $0.005-0.99$. The total pore volume was calculated based on nitrogen volume at the highest relative pressure. The average pore diameter was determined using the Barrett-Joyner-Halenda (BJH) method. Samples were degassed at $250{ }^{\circ} \mathrm{C}$ overnight before analysis.

Crystallographic information on the synthesized materials was obtained by performing powder X-ray diffraction (XRD). The diffraction intensity- $2 \theta$ spectra were acquired using a 
Siemens D 500/501 with $\mathrm{Cu} K_{\alpha}$ radiation $(\lambda=1.54178 \AA$ A $)$ at a scanning rate of $0.04^{\circ} / 2 \mathrm{~s}$.

The morphology of the synthesized materials was examined by performing scanning electron microscopy (SEM) using a JEOL 6300 microscope coupled with energy-dispersive X-ray analysis (EDX; Oxford Link ISIS-2000) to determine local elemental composition.

\subsection{DCFC fabrication}

The fuel cell experiments were performed in an oxygen-anion $\left(\mathrm{O}^{2-}\right)$ conducting cell (Fig. 1). The cell consists of an 8 mol\% YSZ tube $(15 \mathrm{~cm}$ long, $16 \mathrm{~mm}$ inside diameter, and 1.2 $\mathrm{mm}$ wall thickness) as the electrolyte, closed flat at the bottom end. The open end of the YSZ tube was clamped to a stainless-steel, gas-tight cap. The cap has provisions for inlet and outlet gas lines, as well as a hollow cooling ring where a flow of cooling water protects the sealing o-rings. The cathode electrode (Ag) was prepared from silver paste $(05 \mathrm{X}$ metallo-organic Ag resinate), calcined in static air at $850{ }^{\circ} \mathrm{C}$ for $2 \mathrm{~h}$, and deposited onto the outside bottom wall of the YSZ tube. The anodic (working) electrode was prepared from $\mathrm{Cu} / \mathrm{CeO}_{2}$ powder (see Section 2.1) mixed with ethylene glycol. This viscous suspension was deposited by painting it on the inside bottom of the YSZ tube to form an electrode with a superficial surface area of $1.7 \mathrm{~cm}^{2}$. The calcination procedure involved heating in air at $250{ }^{\circ} \mathrm{C}$ for $1 \mathrm{~h}$ and at $850{ }^{\circ} \mathrm{C}$ for $2 \mathrm{~h}$, and then cooling in a reducing atmosphere $\left(10 \% v / v \mathrm{H}_{2}\right.$ in $\left.\mathrm{He}\right)$. Heating and cooling rates were $4{ }^{\circ} \mathrm{C} / \mathrm{min}$. Two Au wires anchored on the electrodes surface were employed to establish the necessary electrical connections. To improve electrical contact at the cathode electrode, a thin Au film was applied to the attached $\mathrm{Au}$ wire on the Ag electrode surface.

\subsection{DCFC testing}

Pure $\mathrm{He}$ and $\mathrm{CO}_{2}$ (both $99.99 \%$ purity, Air Liquide) were employed as purging gases. The gas flow was controlled by mass-flow meters (Tylan FM 360), and introduced into the

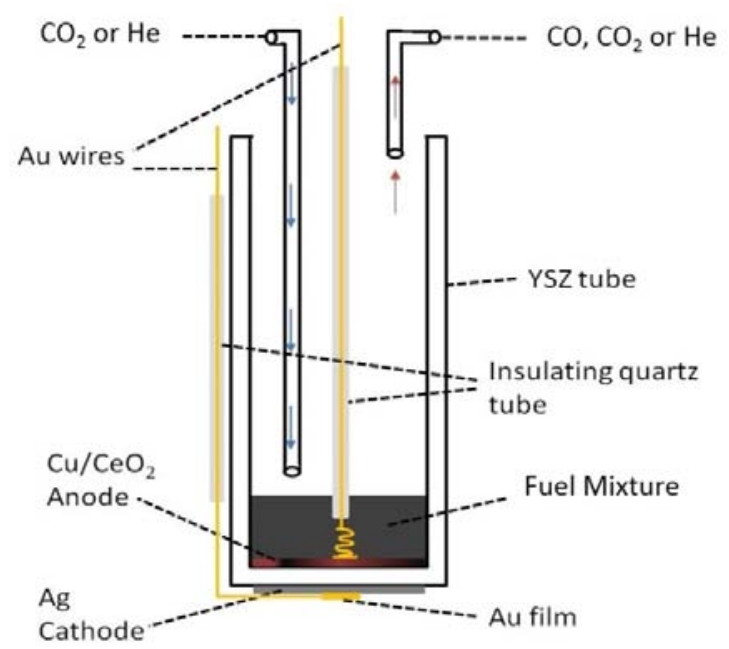

Fig. 1. Schematic illustration of the direct carbon fuel cell (DCFC). reactor cell at a rate of $30 \mathrm{~cm}^{3} / \mathrm{min}$ (STP conditions). In each experiment the cell was loaded either with $800 \mathrm{mg}$ of carbon or a carbon/catalyst mixture (800 $\mathrm{mg}$ carbon:400 $\mathrm{mg}$ catalyst). Experiments were performed at 750 and $800{ }^{\circ} \mathrm{C}$ under atmospheric conditions. Cell voltage and electrical current were monitored with digital multimeters (Uni-T UT 55), and the external resistive load was controlled by a resistance box (Time Electronics 1065). The electrochemical impedance spectra were obtained under open circuit conditions in the frequency range between $0.1 \mathrm{~Hz}$ and $1 \mathrm{MHz}$ with an amplitude of $30 \mathrm{mV}$ RMS. The Versa Stat 4 electrochemical workstation (Princeton Applied Research) and its corresponding software (Versa Studio) were used for data processing. Gas chromatography (GC) analysis of the effluent stream was performed using a Shimadzu GC-14B gas chromatograph equipped with a 13X molecular sieve and a Porapak $\mathrm{N}$ columns. The $\mathrm{CO}$ and $\mathrm{CO}_{2}$ concentrations were also continuously monitored using a Rosemount Binos 100 infrared $\mathrm{CO}-\mathrm{CO}_{2}$ analyzer.

\section{Results and discussion}

\subsection{Characterization studies}

\subsubsection{Textural characterization}

To elucidate the catalyst's effect on the carbon feedstock's textural characteristics, the BET surface area, total pore volume, and average pore size diameter of the carbon, catalyst, and carbon/catalyst mixtures were determined using multipoint BET analysis (Table 1).

The catalyst had a low BET surface area of $45 \mathrm{~m}^{2} / \mathrm{g}$ and a total pore volume of $0.15 \mathrm{~cm}^{3} / \mathrm{g}$. By contrast, the carbon feedstock had a BET surface area of $231 \mathrm{~m}^{2} / \mathrm{g}$ and a total pore volume of $0.56 \mathrm{~cm}^{3} / \mathrm{g}$. The carbon/catalyst mixture $(800 \mathrm{mg}$ carbon $+400 \mathrm{mg}$ catalyst) exhibited a reduced BET area of 162 $\mathrm{m}^{2} / \mathrm{g}$, which is approximately equivalent to the theoretical value expected for a physical mixture $\left(169 \mathrm{~m}^{2} / \mathrm{g}\right)$. This result suggests that the wet impregnation method for feedstock preparation does not significantly modify the carbon feedstock's specific surface area. However, the observed catalyst-induced increase in total pore volume and mean pore diameter (Table 1) indicates that the catalyst strongly affects the porosity of the carbon. This may be due to the incorporation of catalyst particles into the carbon structure. Here, depending on the individual size of the carbon and catalyst particles and their weight ratio, the incorporation of catalyst into the carbon structure could increase its pore volume. Furthermore, the textural characteristics of the carbon/catalyst mixtures may have been affected by the synthesis procedure of $n$-hexane dilution and ultrasonic pretreatment. Previous work in this area has shown

Table 1

Textural characteristics of catalyst $\left(\mathrm{Cu} / \mathrm{CeO}_{2}\right)$, carbon, and carbon/ catalyst mixture.

\begin{tabular}{lccc}
\hline Sample & $\begin{array}{c}S_{\text {BET }} \\
\left(\mathrm{m}^{2} / \mathrm{g}\right)\end{array}$ & $\begin{array}{c}\text { Total pore } \\
\text { volume }\left(\mathrm{cm}^{3} / \mathrm{g}\right)\end{array}$ & $\begin{array}{c}\text { Mean pore } \\
\text { diameter }(\mathrm{nm})\end{array}$ \\
\hline Catalyst & 45 & 0.15 & 13 \\
Carbon & 231 & 0.56 & 10 \\
Carbon/catalyst & 162 & 0.65 & 16 \\
\hline
\end{tabular}




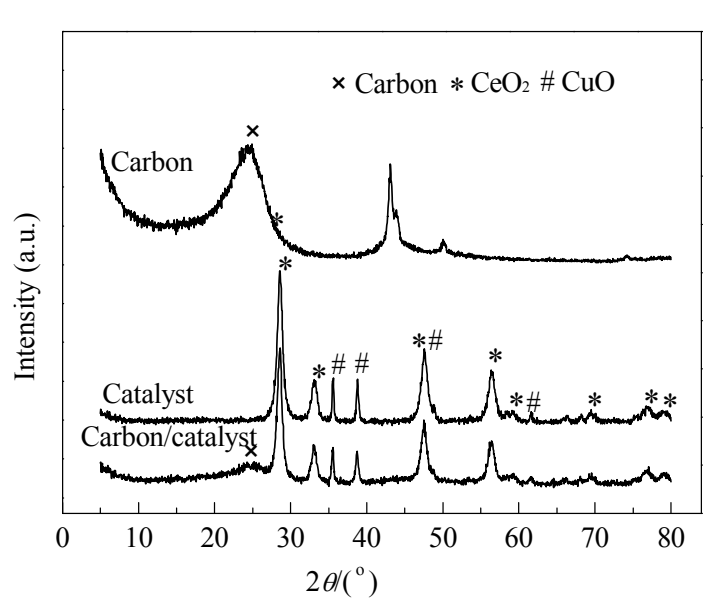

Fig. 2. XRD patterns of the carbon feedstock, the catalyst $\left(\mathrm{Cu} / \mathrm{CeO}_{2}\right)$, and the carbon/catalyst mixture.

that carbon supports with high surface area and adequate porosity can facilitate both reactant-diffusion and electron-transfer [30].

\subsubsection{Structural and morphological analyses}

Figure 2 presents XRD patterns of the carbon feedstock, the $\mathrm{Cu} / \mathrm{CeO}_{2}$ catalyst, and the carbon/catalyst mixture. The carbon feedstock's pattern has a distinctively asymmetrical wide peak centered at approximately $2 \theta=25^{\circ}$, which is attributed to the (002) reflection of graphite, although it is extremely diffuse compared with that of ideal graphite [31]. In addition, the weak, sharp peak at $2 \theta=44^{\circ}$ corresponds to the (100) graphite crystal phase reflection [32]. These peaks are characteristic of short-range graphite-like structures [33]. A weaker peak signal at $2 \theta=25^{\circ}$ is observed for graphitic carbon in the carbon/catalyst mixture, though the peak is dominated by the $\mathrm{CeO}_{2}$ and $\mathrm{CuO}$ phases observed for the catalyst sample. Therefore, no new phases evolve during carbon/catalyst sample preparation, implying a behavior that is typical for physical mixtures.

The SEM/EDX study of the carbon/catalyst sample (Fig. 3) revealed agglomerated materials containing particles ranging in size from submicron to a few micrometers. EDX detected a uniform elemental distribution in the samples that showed no distinct spatial distributions of carbon or metal oxides.

The effect of physicochemical characteristics of the carbonaceous feedstock and the impact of catalyst incorporation into the carbon framework have been extensively reviewed by Lahijani et al. [34]. It was reported that the reactivity of carbon in the gasification process was strongly influenced by the pore structure of the carbon and its morphology, as well as by the availability of active carbon sites [34]. Furthermore, several operational parameters, including temperature, pressure, gasification agent, size of carbon particles and use of catalysts, were found to have a complex influence on the reactivity of the carbon feedstock in the $\mathrm{CO}_{2}$-gasification process [34]. Regarding the impact of the catalyst employed, in most cases the pronounced effect of catalyst was attributed to the increase of reaction centers which play a critical role in the gasification progress. In this regard, the catalytic activity of several materials is

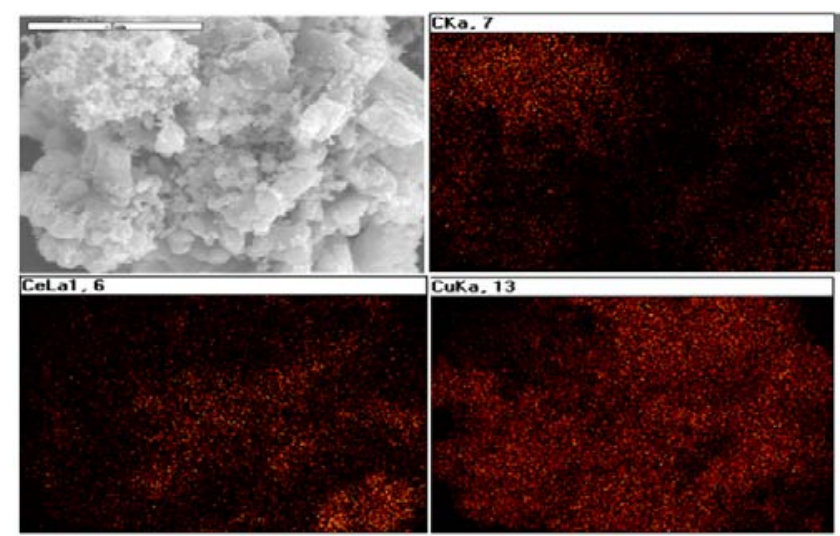

Fig. 3. Representative SEM images (magnification $\times 10000$ ) of the carbon/catalyst mixture and the corresponding elemental maps.

remarkable only when they are well dispersed within the carbon matrix. It has also been reported that incorporating the catalyst into the carbon framework modified the surface chemistry of the carbon and enhanced its physicochemical properties, which eventually contributed to higher gasification reactivities [34].

\subsection{DCFC performance}

\subsubsection{Effect of $\mathrm{Cu} / \mathrm{CeO}_{2}$ catalyst as a carbon additive}

Figure 4 presents the effect of the $\mathrm{Cu} / \mathrm{CeO}_{2}$ catalyst on DCFC performance characteristics, including cell voltage, current density, and power density, at 750 and $800{ }^{\circ} \mathrm{C}$ under a flowing He atmosphere, and with a constant carbon/catalyst weight ratio of 2 . The increase in cell temperature and the addition of catalyst to the carbon feedstock both clearly improve cell performance. Catalyst addition results in a maximum power of 5.0 and $7.3 \mathrm{~mW} / \mathrm{cm}^{2}$ at 750 and $800{ }^{\circ} \mathrm{C}$, respectively, compared with that for the bare carbon feedstock (3.0 and $4.6 \mathrm{~mW} / \mathrm{cm}^{2}$ at 750 and $800{ }^{\circ} \mathrm{C}$, respectively). These catalyst-mediated improvements may be due to the pronounced effect of catalyst on carbon electro-oxidation kinetics [21], which is further discussed in subsequent sections. Kulkarni et al. [35] studied the performance of $\mathrm{La}_{0.3} \mathrm{Sr}_{0.7} \mathrm{Ti}_{0.93} \mathrm{Co}_{0.07} \mathrm{O}_{3}$ (LSCT) as the anode material in a DCFC of the type LSCT/YSZ/LSCF that was fed with carbon black (Vulcan XC-72, Cabot Corp.) at $800{ }^{\circ} \mathrm{C}$ and employed pure $\mathrm{N}_{2}$ as the carrier gas. They reported a maximum power density of $7.5 \mathrm{~mW} / \mathrm{cm}^{2}$, which is similar to that obtained in the present work.

Figure 4(b) presents the corresponding open circuit (OC) AC impedance spectra obtained at the same conditions as those employed to generate the data in Fig. 4(a). It is clearly shown that both the ohmic (intercept of the high frequency arc with the real axis) and electrode resistances are substantially decreased upon increasing cell temperature and adding the $\mathrm{Cu} / \mathrm{CeO}_{2}$ catalyst into carbon feedstock. These results are in agreement with the observed changes to DCFC performance characteristics (Fig. 4(a)). Specifically, the ohmic resistance decreased from 11.4 to $8.1 \Omega \mathrm{cm}^{2}$ upon increasing temperature from 750 to $800{ }^{\circ} \mathrm{C}$. A further decrease of the ohmic resistance to $5.5 \Omega \mathrm{cm}^{2}$ at $800{ }^{\circ} \mathrm{C}$ was obtained by catalyst incorporation 

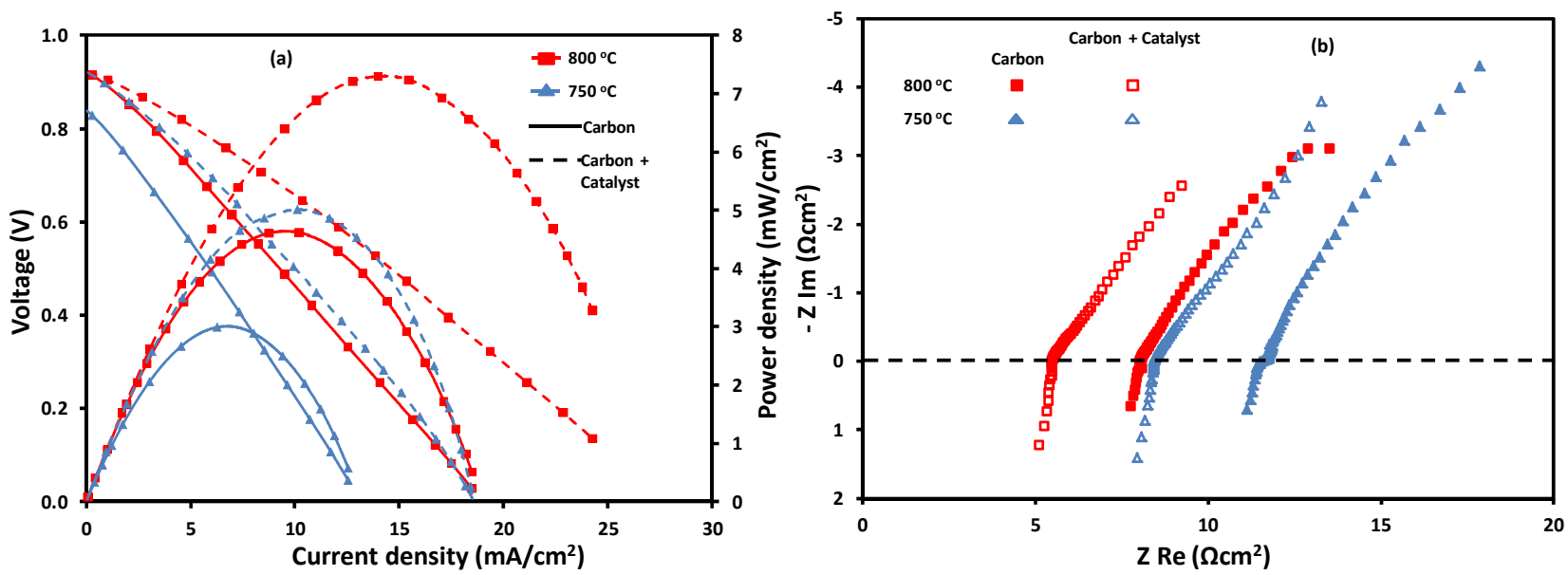

Fig. 4. (a) Effect of catalyst addition on direct carbon fuel cell performance at 750 and $800{ }^{\circ} \mathrm{C}$ employing He as the carrier gas and (b) the corresponding AC impedance spectra. Carbon loading $=800 \mathrm{mg}$; catalyst $\left(\mathrm{Cu} / \mathrm{CeO}_{2}\right)$ loading $=400 \mathrm{mg}$; He flow $=30 \mathrm{~cm}^{3} / \mathrm{min}$.

into the carbon feedstock. A similar trend was obtained for the electrode resistances, as reflected by the size of the two overlapping arcs. The dominant feature in the impedance spectra is the overlap of the small high-frequency arc with the large low-frequency arc. The size of both arcs decreases significantly by increasing the cell temperature and by infusing catalyst in the carbon feedstock.

Through ensuring that the cathodic atmosphere and the material for the anode, the cathode and the electrolyte were identical in the examined cases, the alterations in the AC impedance spectra at a constant temperature can be attributed to the catalyst infusion into the carbon feedstock. More specifically, as shown in Fig. 6, even under a He atmosphere the CO formation rate increased in the presence of the catalyst. This surplus CO can improve DCFC performance (Fig. 4(a)) due to its faster diffusion and electro-oxidation rates compared to solid carbon. Furthermore, the differences observed in the ohmic resistance at the same cell temperature can plausibly be ascribed to the increased electrical conductivity of the anode due to its partial reduction by the excess $\mathrm{CO}$. In addition, even in the inert $(\mathrm{He})$ atmosphere, $\mathrm{CO}_{2}$ could be formed through the direct electro-oxidation of carbon or CO via reactions (1) and (3), respectively. Any produced $\mathrm{CO}_{2}$ can therefore undergo the reverse-Boudouard reaction (4) to generate additional $\mathrm{CO}$, which then can be electro-oxidized at the anode TPB sites.

\subsubsection{Combined effect of catalyst and gasification agent}

To understand the importance of in situ carbon gasification via the catalyst-aided reverse-Boudouard reaction, the effect of the carrier gas on DCFC performance characteristics at $800{ }^{\circ} \mathrm{C}$ was examined with and without the catalyst (Fig. 5). In both cases switching from $\mathrm{He}$ to $\mathrm{CO}_{2}$ enhances the cell power output by approximately $45 \%$.

The absolute open circuit voltage (OCV) values were higher for the He atmosphere; however, they didn't change upon catalyst addition (Fig. 5). It should be pointed out that the complex network of chemical and electrochemical reactions taking place in the anodic chamber and at the anode/electrolyte and the anode/fuel interfaces, makes it difficult to predict the equilibrium oxygen concentration and thus the theoretical OCV. Furthermore, OCV can be notably affected by the fuel's physicochemical properties (i.e., reactivity, conductivity, morphology,
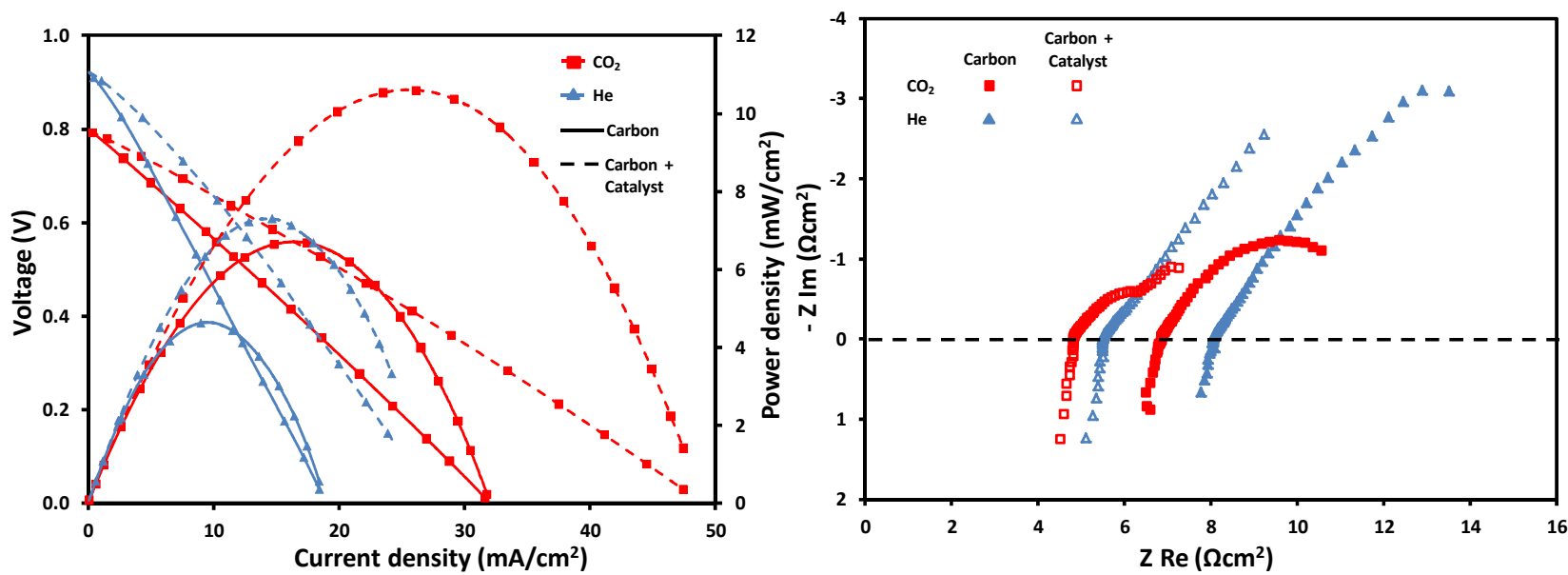

Fig. 5. (a) Effect of two carrier gases $\left(\mathrm{He}, \mathrm{CO}_{2}\right)$ on direct carbon fuel cell performance with and without a catalyst infused into the carbon feedstock and (b) the corresponding AC impedance spectra. Carbon loading $=800 \mathrm{mg}$; catalyst $\left(\mathrm{Cu} / \mathrm{CeO}_{2}\right)$ loading $=400 \mathrm{mg}$; total carrier gas flow rate $=30$ $\mathrm{cm}^{3} / \mathrm{min}$. 
crystal structure, and fluidity), carrier gas type (inactive $\mathrm{He}$ or reactive $\mathrm{CO}_{2}$ ) and operating conditions (i.e., temperature, carrier gas flow rate and carbon loading) [36]. It can therefore be assumed that the equilibrium oxygen concentration and the OCV are dependent on a number of factors including the fuel characteristics, the chemical reactions taking place at the anode surface and the charge transfer reactions occurring at the TPB as well as the gas phase environment surrounding the anode.

The inferior power output under He flow can be mainly attributed to mass transfer limitations at the anode due to the limited interaction between solid carbon and the solid electrolyte/electrode interface. However, a notable improvement in DCFC performance was obtained under $\mathrm{CO}_{2}$ flow, which can be ascribed to in situ CO formation via the reverse-Boudouard reaction $[23,24]$ and its subsequent diffusion and electro-oxidation at the anodic TPB. Furthermore, this additional CO was thought to modify the electrical conductivity of the $\mathrm{Cu} / \mathrm{CeO}_{2}$ anode electrode, as shown by the overall cell resistances.

The aforementioned arguments are clearly reflected on the corresponding AC impedance spectra shown in Fig. 5(b). From a value of $8.1 \Omega \mathrm{cm}^{2}$ for the bare carbon feedstock, the ohmic resistance substantially decreased to 4.8 and $6.8 \Omega \mathrm{cm}^{2}$ for carbon/catalyst $/ \mathrm{CO}_{2}$ and carbon/ $/ \mathrm{CO}_{2}$ configurations, respectively. In addition, the electrode resistance decreased when both $\mathrm{CO}_{2}$ and catalyst were used as carrier gas and carbon additive, respectively. Particularly for the results derived without using the catalyst, the high frequency arc is lower when the anode is exposed to He while the opposite trend is observed for the low frequency arc. However, catalyst infusion into the carbon feedstock with $\mathrm{CO}_{2}$ as the carrier gas results in a larger high frequency arc followed by a decreased low frequency arc. Taking into account the above aspects and the reaction steps proposed in Ref. [35], two suggestions are made to describe this behavior. First, the high frequency arc, which is enlarged by both $\mathrm{CO}_{2}$ as the carrier gas and especially when the catalyst is infused into the carbon feedstock, can be mainly ascribed to the electro-oxidation of carbon and the associated physical processes (adsorption/desorption and diffusion of reactive species). Second, the low frequency arc, which is notably reduced with $\mathrm{CO}_{2}$ as the carrier gas, could be ascribed to the electro-oxidation of $\mathrm{CO}$ and the corresponding physicochemical processes.

To verify the catalyst's role in $\mathrm{CO}$ formation and the effect on cell performance of $\mathrm{CO}$ generated in situ, the transient response of the $\mathrm{CO}$ formation rate to step changes in carrier gas (He to $\mathrm{CO}_{2}$ ) was investigated at $800{ }^{\circ} \mathrm{C}$ for the carbon feedstock and carbon/catalyst mixture under OC and closed circuit (CC) conditions (Fig. 6). During the first stage ( $t=0-30 \mathrm{~min})$, He flowed into the anode chamber under OC operation until the OCV stabilized. In the second stage ( $t=30-75 \mathrm{~min})$, the circuit was closed and a constant cell voltage that corresponds to maximum power conditions was applied. In the last stage $(t=$ 75-120 min), the circuit was opened again until a steady state OCV was obtained. $\mathrm{CO}_{2}$ was then introduced to the cell $(t=120$ $\mathrm{min}$ ), and the previous stages carried out under a He atmosphere were repeated. Under a He atmosphere and OC condi-

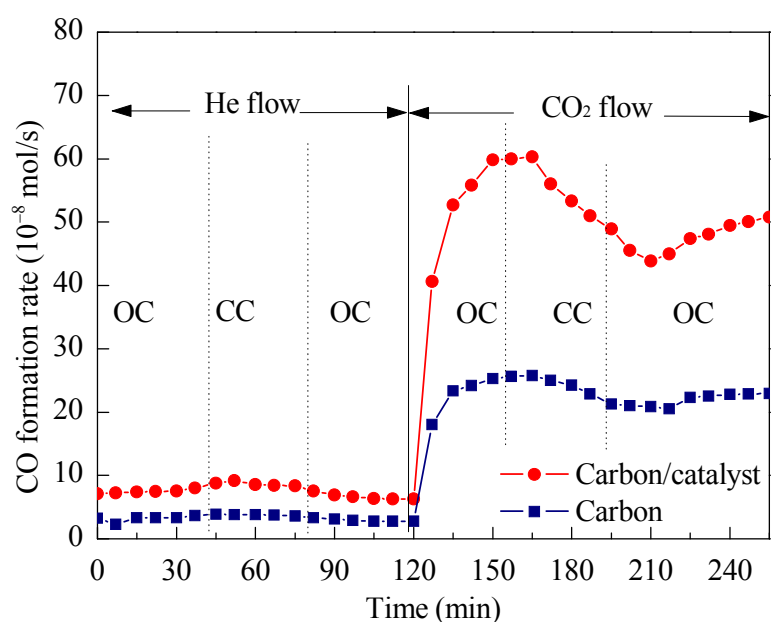

Fig. 6. Transient changes in $\mathrm{CO}$ formation rate in response to step changes in carrier gas at $800{ }^{\circ} \mathrm{C}$ under open circuit (OC) and closed circuit (CC) conditions. Carbon loading $=800 \mathrm{mg}$; catalyst $\left(\mathrm{Cu} / \mathrm{CeO}_{2}\right)$ loading $=0$ or $400 \mathrm{mg}$; carrier gas flow rate $=30 \mathrm{~cm}^{3} / \mathrm{min}$.

tions, the CO formation rates were approximately $3.3 \times 10^{-8}$ and $7.4 \times 10^{-8} \mathrm{~mol} / \mathrm{s}$ for the bare carbon feedstock and the carbon/catalyst mixture, respectively. This difference can be ascribed to the presence of $\mathrm{CO}_{2}$ in the anode compartment $\left(\sim 5.0 \times 10^{-8}\right.$ and $10 \times 10^{-8} \mathrm{~mol} / \mathrm{s}$ without and with the catalyst, respectively), which undergoes the un-catalyzed (carbon/ $/ \mathrm{CO}_{2}$ ) or catalyzed (carbon/catalyst/ $\mathrm{CO}_{2}$ ) reverse-Boudouard reaction, forming $\mathrm{CO}$. The $\mathrm{CO}$ formation rate is higher in the latter case due to the beneficial effect of the catalyst on the reverse-Boudouard reaction. The formation of a small amount of $\mathrm{CO}_{2}$, even under a $\mathrm{He}$ atmosphere and OC conditions, can be explained by taking into account the oxidation of carbon by different oxygen species. These oxygen species could be derived from the oxygen functional groups of carbon feedstock, the lattice oxygen of solid electrolyte (YSZ) or anodic electrode $\left(\mathrm{Cu} / \mathrm{CeO}_{2}\right)$, the carrier gas impurities, or other sources.

Under closed circuit conditions ( $t=30-75 \mathrm{~min}$, Fig. 6), the $\mathrm{CO}$ and $\mathrm{CO}_{2}$ formation rates slightly increased both with and without the catalyst. However with the catalyst, where the increases were more obvious, the $\mathrm{CO}$ formation rate increased from $7.4 \times 10^{-8}$ to $8.6 \times 10^{-8} \mathrm{~mol} / \mathrm{s}$. The rate of $\mathrm{CO}_{2}$ formation increased by the same amount $\left(1.2 \times 10^{-8} \mathrm{~mol} / \mathrm{s}\right)$ from $1.03 \times 10^{-7}$ to $1.15 \times 10^{-7} \mathrm{~mol} / \mathrm{s}$. The increase in CO formation rate under these specific conditions indicates that the rate at which $\mathrm{CO}$ is formed through the partial electro-oxidation of carbon and the reverse Boudouard reaction is higher than the rate at which $\mathrm{CO}$ undergoes electro-oxidation to $\mathrm{CO}_{2}$. Conversely, the increment in $\mathrm{CO}_{2}$ formation rate implies that the reaction rates for the complete electro-oxidation of carbon and the in situ formation of $\mathrm{CO}_{2}$ from $\mathrm{CO}$ electro-oxidation are together greater than the consumption rate of $\mathrm{CO}_{2}$ by the reverse-Boudouard reaction.

With $\mathrm{CO}_{2}$ as the carrier gas and under OC conditions, the rate of CO production was significantly higher for the carbon/catalyst mixture than for the bare carbon feedstock (Fig. 6). These results reveal the beneficial effect of the catalyst on the CO formation rate through the catalyzed re- 
verse-Boudouard reaction. Under CC with the same carrier gas the CO formation rate decreased from $2.5 \times 10^{-7}$ to $2.0 \times 10^{-7}$ $\mathrm{mol} / \mathrm{s}$ for the carbon feedstock and decreased from $6.0 \times 10^{-7}$ to $4.4 \times 10^{-7} \mathrm{~mol} / \mathrm{s}$ for the carbon/catalyst mixture. This decrease, observed in both cases, is explained by the electro-oxidation of the CO that was formed in situ during DCFC operation.

Other work in this field has reported that the addition of $\mathrm{Sn}$ to carbon-black in a SOFC with a Ni/YSZ anode enhanced the power density compared with the Sn-free fuel by 4-fold, which was attributed to Sn-facilitation of carbon-oxidation kinetics [37]. Similar conclusions for the effect of $\mathrm{He}$ or $\mathrm{CO}_{2}$ as the carrier gas on DCFC performance have been reported for a LSF/GCO/LSF-Ag cell that was fueled with carbon; DCFC performance was enhanced under a $\mathrm{CO}_{2}$ atmosphere at temperatures higher than $700{ }^{\circ} \mathrm{C}$ due to the higher amount of $\mathrm{CO}$ formation and its electro-oxidation at the TPB [14]. The increased performance of a Ni/YSZ anode-supported SOFC with coke fuel and $\mathrm{CO}_{2}$ as the carrier gas was attributed to the increased electrochemical oxidation of CO [16]. Recent work has also established a close correlation between the $\mathrm{CO}$ formation rate under OC conditions and cell performance [36].

The results obtained in the current work are consistent with these previous studies and confirm that the enhanced DCFC performance in terms of power output in the presence of $\mathrm{CO}_{2}$ is due to the faster rates of diffusion and electro-oxidation of the CO produced by the catalyzed reverse-Boudouard reaction at the anodic TPB. A schematic diagram of the process is shown in Fig. 7.

\subsubsection{DCFC optimization}

Considering the results presented in this study, the following four aspects should be accounted for during DCFC optimization.

(1) Catalyst incorporation into the carbon feedstock can result in improved DCFC performance independently of the carrier gas used. This emphasizes the key role of the catalyst in the overall cell efficiency.

(2) The presence of $\mathrm{CO}_{2}$ in the anode compartment can lead to superior DCFC performance compared with that when He is present.

(3) The CO formation rate is substantially accelerated in the

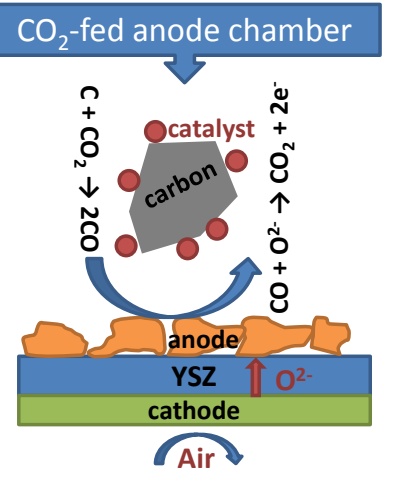

Fig. 7. Schematic illustration of the proposed concept. CO formed through the catalyst-aided reverse-Boudouard reaction is diffused and electro-oxidized at the anode TPB sites leading to an improvement in power output. presence of both $\mathrm{CO}_{2}$ and the catalyst, as the catalyst promotes carbon gasification via the reverse-Boudouard reaction.

(4) An increase in the amount of CO formed in situ improves DCFC performance as CO bypasses mass-transfer limitations and displays higher rates of electro-oxidation than solid carbon.

It is important to note the limited power densities obtained in the present study, even for the best-performing DCFC configuration. These power outputs were considered to have been limited primarily by the ohmic resistances attributed to the YSZ solid electrolyte membrane (thickness of approximately 1.2 $\mathrm{mm}$ ), the anodic and cathodic electrodes, and poor contact and adherence of electrodes on the YSZ surface. Therefore, work is in progress to develop state-of-the-art cells with thin solid electrolyte membranes and employing more sophisticated electrode deposition techniques which could considerably enhance DCFC performance. Other work that increases CO production by recirculating off-gases or optimizes SOFC geometries for continuous operation at maximum current output is also needed prior to widespread deployment of DCFCs.

\section{Conclusions}

This study explores strategies to enhance the performance of carbon-fueled SOFCs of the type carbon|Cu-CeO2/YSZ/Ag|air. Through fuel cell experiments accompanied by AC impedance spectroscopy studies, a novel approach was tested that involved the simultaneous use of $\mathrm{Cu}$-based catalysts as carbon additives and $\mathrm{CO}_{2}$ as a gasifying agent. Promising results were obtained in terms of DCFC output characteristics at $800{ }^{\circ} \mathrm{C}$; the maximum power output was enhanced by approximately $40 \%$ and $230 \%$ for carbon/ $\mathrm{CO}_{2}$ and carbon/catalyst $/ \mathrm{CO}_{2}$ configurations, respectively, compared with that of the carbon/He system. These results clearly demonstrate the benefits of catalyst infusion into the carbon feedstock. The beneficial impact on performance can be attributed to the catalyst's pronounced effect on the reverse-Boudouard reaction rate and the subsequent diffusion and electro-oxidation at the anodic TPB of CO formed in situ. A number of contributions to improving DCFCs' performance characteristics were provided through a catalyst-aided gasification process that offers the potential of development of carbon fuel cells without the need for highly corrosive carbonates.

\section{Acknowledgments}

The authors would like to acknowledge financial support from the EU project "Efficient Conversion of Coal to Electricity Direct Coal Fuel Cells" which is funded by the Research Fund for Carbon \& Steel (RFCR CT-2011-00004) and King Abdulaziz City for Science and Technology, Riyadh, Saudi Arabia.

\section{References}

[1] International Energy Outlook 2011, U.S. Energy Information administration, http: // www.eia.gov / forecasts / ieo / pdf / 0484 (2011). pdf

[2] Wang J G, Li Y W, Han Y Z, Sun Y H, Fang Y T, Zhao J T, Qin Z F. Chin 


\section{Graphical Abstract}

Chin. J. Catal., 2015, 36: 509-516 doi: 10.1016/S1872-2067(14)60262-X

\section{Carbon to electricity in a solid oxide fuel cell combined with an internal catalytic gasification process}

M. Konsolakis*, G. E. Marnellos, A. Al-Musa, N. Kaklidis, I. Garagounis, V. Kyriakou

Technical University of Crete, Greece; University of Western Macedonia, Greece; Chemical Process \& Energy Resources Institute, Greece; King Abdulaziz City for Science and Technology, Saudi Arabia; Aristotle University of Thessaloniki, Greece

\section{Catalyst-aided Direct Carbon Fuel Cell (DCFC) concept}
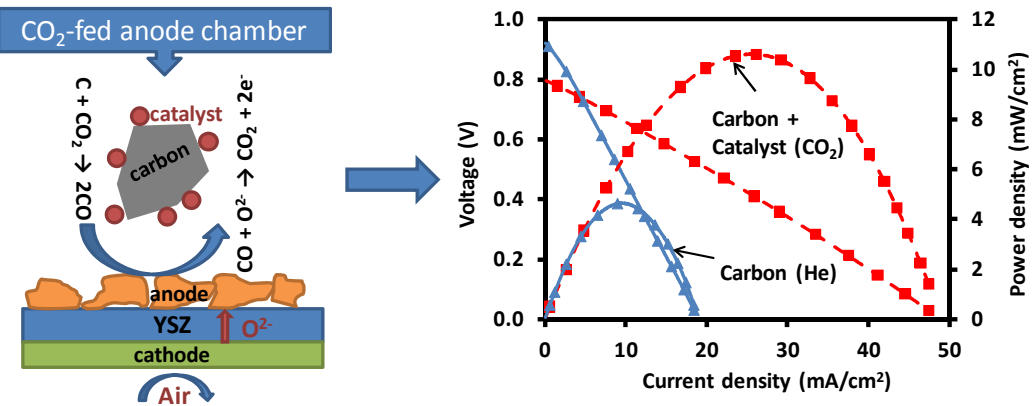

The feasibility of enhancing the performance of direct carbon fuel cells by an internal, catalyst-aided carbon gasification process is explored. The maximum power is 3 -fold enhanced in comparison to bare carbon (He) configuration.

J Catal (王建国, 李永旺, 韩怡卓, 孙予罕, 房倚天, 赵建涛, 秦张 峰. 催化学报), 2009, 30: 770

[3] Giddey S, Badwal S P S, Kulkarni A, Munnings C. Prog Energ Combust Sci, 2012, 38: 360

[4] Kirubakaran A, Jain S, Nema R K. Renew Sust Energ Rev, 2009, 13: 2430

[5] Wu W M, Liu Z B, Zhao Z, Zhang X M, Ou D R, Tu B F, Cui D A, Cheng M J. Chin J Catal (武卫明, 刘中波, 赵哲, 张小敏, 区定容, 涂宝峰, 崔大安, 程谟杰. 催化学报), 2014, 35: 1376

[6] Zhang L M, Cong Y, Yang W S, Lin L W. Chin J Catal (张丽敏, 从铀, 杨维慎, 林励吾. 催化学报), 2007, 28: 749

[7] Rady A C, Giddey S, Badwal S P S, Ladewing B P, Bhattacharya S. Energy Fuels, 2012, 26: 1471

[8] Gür T M. Chem Rev, 2013, 113: 6179

[9] Li X, Zhu Z, De Marco R, Bradley J, Dicks A. J Phys Chem A, 2010, 114: 3855

[10] Nürnberger S, Bussar R, Desclaux P, Franke B, Rzepka M, Stimming U. Energy Environ Sci, 2010, 3: 150

[11] Zhang J B, Zhong Z P, Zhao J X, Yang M, Li W L, Zhang H Y. Can J Chem Eng, 2012, 90: 762

[12] Lee C G, Ahn K S, Lim H C, Oh J M. J Power Sources, 2004, 125: 166

[13] Jain S, Lakeman B, Pointon K D, Irvine J T. In: Eguchi K, Singhai S C, Yokokawa H, Mizusaki H, Eds. Solid Oxide Fuel Cells 10 (SOFC-X). New York: the Electrochemical Society, 2007. 829

[14] Zecevic S, Patton E M, Parhami P. Carbon, 2004, 422: 1983

[15] Cherepy N J, Krueger R, Fiet K J, Jankowski A F, Cooper J F. J Electrochem Soc, 2005, 152: A80

[16] Dicks A L. J Power Sources, 2006, 156: 128

[17] Cao D X, Sun Y, Wang G L. J Power Sources, 2007, 167: 250

[18] Tang Y B, Liu J. Int J Hydrogen Energy, 2011, 35: 11188

[19] Gür T M, Homel M, Virkar A V.J Power Sources, 2010, 195: 1085
[20] Li C, Shi Y X, Cai N S. J Power Sources, 2010, 195: 4660

[21] Nabae Y, Pointon K D, Irvine J T S. J Electrochem Soc, 2009, 156: B716

[22] Wu Y Z, Su C, Zhang C M, Ran R, Shao Z P. Electrochem Commun, 2009, 11: 1265

[23] Chien A C, Chuang S S C. J Power Sources, 2011, 196: 4719

[24] Chien A C, Siengchum T, Chuang S S C. ECS Trans, 2011, 33: 75

[25] Gorte R J, Vohs J M. J Catal, 2003, 216: 477

[26] Tang X L, Zhang B C, Li Y, Xu Y D, Xin Q, Shen W J. Appl Catal A, 2005, 288: 116

[27] Chen G X, Li Q L, Wei Y C, Fang W P, Yang Y Q. Chin J Catal (陈国星, 李巧灵, 魏育才, 方维平, 杨意泉. 催化学报), 2013, 34: 322

[28] Zhan W C, Guo Y, Gong X Q, Guo Y L, Wang Y Q Lu G Z. Chin J Catal (詹望成, 郭耘, 龚学庆, 郭扬龙, 王艳芹, 卢冠忠. 催化学报), 2014, 35: 1238

[29] Sun J F, Zhang L, Ge C Y, Tang C J, Dong L. Chin J Catal (孙敬方, 张 雷, 葛成艳, 汤常金, 董林. 催化学报), 2014, 35: 1347

[30] Antolini E. Appl Catal B, 2009, 88: 1

[31] Li X, Zhu Z H, De Marco R, Bradley J, Dicks A.J Power Sources, 2010, 195: 4051

[32] Li X, Zhu Z H, Chen J L, de Marco R, Dicks A, Bradley J, Lu G Q. J Power Sources, 2009, 186: 1

[33] Lu L M, Kong C H, Sahajwalla V, Harris D. Fuel, 2012, 81: 1215

[34] Lahijani P, Zainal Z A, Mohammadi M, Mohamed A R. Renew Sust Energ Rev, 2015, 41: 615

[35] Kulkarni A, Giddey S, Badwal S P S, Paul G. Electrochim Acta, 2014, 121: 34

[36] Kaklidis N, Kyriakou V, Garagounis I, Arenillas A, Menéndez J A, Marnellos G E, Konsolakis M. RSC Adv, 2014, 4: 18792

[37] Ju H K, Uhm S, Kim J W, Song R H, Choi H, Lee S H, Lee J. J Power Sources, 2012, 198: 36 